A könyv első része egy elméleti és utazási elmélettörténeti bevezetéssel kezdődik, ebben a „Grand Tour” szokásának kialakulását követi nyomon a szerző. Az ezt követő két alfejezet egy nagyon alapos, negyedszáz oldalas kutatási program leírása, jelezve az eddigi eredményeket is. A program az itáliai utazások bibliográfiájának összeállítási lehetőségét és megvalósításának módját mutatja be. Ennek a végén számba veszi azokat a szempontokat, ahogy a tudós vagy a könyvtáros utazó bemutatja az Itáliában általa meglátogatott könyvtárakat, vagyis egy elméleti modellt alkot történeti példákra alapozottan arról, miként mutatható be egy könyvtár.

A kötet második része néhány hatalmas levelezési korpuszt vesz górcső alá, a bollandistáktól kezdődően a 19. századig. Olyak nevekre kell itt gondolnunk, mint a belgiumi bollandista Giodfrey Henschen (1601-1681), a maurista Jean Mabillon (1632-1707), a könyvtáros filozófus Gottfried Wilhelm Leibniz (1746-1716), vagy az a Johann III Bernoulli (1744-1807) matematikus, csillagász, akinek éppen az utazási emlékeit 18 kötetben tették közzé (1781-1878). Külön érdekessége a könyv e részének, hogy olyanok levelezését is áttekinti, akik kifejezetten nem írtak az utazásaik során meglátogatott könyvtárakról (Jean Jacques Barthélemy, Charles Dupaty, Joseph Spence).

A harmadik, legterjedelmesebb része a könyvnek magukat az itáliai könyvtárakat veszi sorra, amelyeket olyan utazók mutattak be a saját hazájuknak, kulturális közösségüknek és persze mindazoknak, akik olvasták útleírásaikat, akiknek utazási naplói vagy elbeszélései kortárs módon nyomtatásban is megjelentek. Ezek, mintegy irodalmi útikalauzként is szolgálhattak aztán másoknak.

Fiammetta Sabba ebben a kötetében természetesen nem vállalkozhatott arra, hogy egy teljes bibliográfiát adjon közre az itáliai útleírásokról, vagy akár csak azokról, amelyekben külön részek szólnak az egyes városok, nagyobb személyiségek könyvtárairól. Ugyanakkor az egyes részek lábjegyzetei, majd a kötet mutató rendszere - lehet például városonként, az egyes könyvtárakra is keresni - kiváló kiindulási pont ahhoz, hogy az itáliai könyvtártörténetet egy újfajta nézőpontból áttekintsük.

MONOK IsTVÁN

\title{
Borsa Gedeon, Újabb könyvtörténeti írások, Csobán Endre Attila közremúködésével, szerk. Szvorényi Róbert, P. Vásárhelyi Judit, Budapest, Argumentum, OSZK, 2018 (A Magyar Könyvszemle és a MOKKA-R Egyesület füzetei, 10). 220 p.
}

A most bemutatandó kötettel a Magyar Könyvszemle és a MOKKA-R Egyesület füzetei sorozat tizedik darabját veheti kézbe az olvasó. A konferenciakötetek, kismonográfiák és tisztelgő kötetek sorában egy újabb meghatározó régi könyves szaktekintélyt köszöntő gyűjtemény jelent meg. A szerkesztók a 95. születésnapja alkalmából Borsa Gedeont köszöntik 18 tanulmánya közreadásával, folytatva a 70. és a 80. születésnapjára kiadott kötetek sorát (Gesta typographorum, A hetvenéves Borsa Gedeon tiszteletére ajánlják e könyvet barátai és tanitványai, szerk. P. Vásárhelyi Judit, Bp., Borda Antikvárium, 1993; Fata libelli, A nyolcvanéves Borsa Gedeon köszöntésére írták barátai és tanitványai = Fata libelli, Ad octoginta annos natum Gedeon Borsa ab amicis discipulisque scripta, szerk. P. Vásárhelyi Judit, Bp., OSZK, 2003). A tucatnyi magyar nyelvü és hat német nyelvü írás a négykötetes Könyvtörténeti írások méltó folytatásaként értelmezhetö, amely - egy kivétellel - az életmü 2000 után született anyagából ad áttekintést. Az idegen nyelvü szövegeket magyar összefoglaló követi. A tanulmányok az első megjelenéskori állapotot tükrözik, a bennük közölt adatokat nem aktualizálták.

Borsa Gedeont aligha kell bemutatnunk a folyóirat olvasóinak, élete során olyan alapvető kézikönyvek szerkesztésében vett részt, mint a Régi magyarországi nyomtatványok vagy az Österreichische Nationalbibliothek 16. századi nyomtatványainak katalógusa. Kisebb munkái közül jó néhány (pl. a régi nyomtatványok anyaga és mérete tárgyában) az egyetemi kurzusokat megalapozó kötelező irodalom része. 
A kötet első részében szereplő tizenkét írás a Hazai és külföldi nyomda-és kiadástörténet címet viseli, kezdő darabja Antonius de Hungaria esztergomi kanonok nyomába ered. Az első esztergomi misekönyv megrendelőjének származásáról, iskolázottságáról és karrierjéről összegyüjtött adatokat olvashatunk.

Ezt követi a Martin Preuss besztercei könyvkereskedő tevékenységével kapcsolatos levél szövege és rövid elemzése. Az irat fennmaradását egy budai kereskedővel folytatott pernek köszönhetjük, általa nyerhetünk betekintést a 16. század eleji erdélyi könyvkereskedelem történetébe.

A harmadik tanulmány az első szebeni nyomda történetéről közöl helyesbítést egy korábbi könyvszemlés cikk kapcsán. A Teleki Tékában örzött, kötéstáblából kiáztatott néhány leveles töredék érdekes adalékkal szolgál mind a nyomda működéséről, mind a város reformációjáról. A búcsúkhoz készült 1525. évi naptárak hátoldalára ugyanis néhány éven belül lutheránus szellemü imádságokat nyomtattak. Fény derül továbbá a szebeni műhely velencei kapcsolataira is.

A negyedik írást olvasva a legelső, 1528. évi hazai nyomdászjelvény nyomába eredhetünk, amely szintén Szeben városához kapcsolódik. Jakó Zsigmond korábbi feltételezéseit kiegészítve Borsa Gedeon arra is magyarázattal szolgál, hogy a nyomódúc hogyan került fél évszázaddal később a Gyulafehérváron ószláv nyomtatványokat kiadó Lorinţ diakónus mühelyébe.

Perger Péter társszerzőségében jelent meg egy terjedelmesebb tanulmány Heltai Újtestamentumainak a brassói papírmalom vízjel nélküli papírra készült kiadásairól. Az egyetlen teljes Újszövetség-példány vizsgálata lehetővé tette az egymástól szedésükben eltérő 1561. és 1562. évi kiadások közötti különbségek megállapítását. A két kiadás születésének okát a szerzőpáros a papírutánpótlás elakadásában látja, s e mögött felekezeti ellentétet fedez fel.

A hatodik írás a VD 16 egyik tételleírása kapcsán felmerült kérdést jár körül, miszerint müködhetett-e 1578-ban nyomda Budán? A törökök által megszállt város természetesen nem adhatott otthont egy múhelynek, a híradás hitelességének látszatát növelni kívánó magdeburgi nyomdász üzleti fogásként alkalmazta az „Erstlich gedruckt zu Offen” jelölést.

A soron következő írásból Laskai Osvát és Temesvári Pelbárt műveinek kiadóiról tájékozódhatunk. A szerző az obszerváns ferencesek 6 müvének 121 kiadványának 54 tételét regisztrálja példás alapossággal. A kiadók és nyomdászok teljes körü számbavétele mellett kiemeli az augsburgi Johannes Rynmann és a hagenaui Heinrich Gran szerepét Laskai és Temesvári munkáinak népszerüsítésében.

Borsa Gedeon nyolcadik írásában a 15-16. századi Magyarországon müködő német származású nyomdászmestereket, bérlöket, tulajdonosokat és örökösöket veszi sorra Andreas Hesstől (1473) a vimpáci ferences testvérekig (1593).

A következő tanulmány a 16. századi konfesszionalizációnak az erdélyi nyomdákra gyakorolt hatását tárja fel. A szebeni, a brassói és a kolozsvári mühelyek szorosan követték a városi lakosság által bevett irányvonalat. A felekezetváltás Kolozsvár esetében az addigi források elapadásával járt: Heltai kénytelen volt saját papírmalmot alapítani.

A szerző korábbi nemzetközi bibliográfiai munkálataihoz kapcsolódik a tizedik írás, amelyben az Osztrák Nemzeti Könyvtárban (ÖNB) őrzött több mint 2000, 16. századi németalföldi kiadványról olvashatunk. Történelmi okai vannak, hogy ennek igen jelentős része a mai Belgium területéről származik. Az ÖNB katalógusában közölt anyagra jellemzö, hogy 18, 1501-1540 között nyomtatott és 40, 1541-1600 között nyomtatott mủ volt eddig ismeretlen a terület bibliográfusai előtt.

Korábban Tóth Béla írt bővebben a debreceni rézmetsző diákok müködéséről, ezúttal Borsa Gedeon két olyan nyomtatványra hívja fel a figyelmet, amelyek Erős Gábor és Pap József kolozsvári nyomdásztevékenységéről tanúskodnak. Megállapítása szerint a Kazinczy által lebecsült, ma csak töredékesen ismert nyomtatott betümintát nem ugyanazzal a készlettel nyomtatták, mint a két említett kolozsvári munkát. 
A fejezet zárásaként a besztercei tipográfia 1813-1949 közötti történetét ismerhetjük meg dióhéjban. Ez idő alatt négy jelentősebb mühely müködött a városban, a Filtsch-Botschaar-,,Minerva” officina, az Orendi-Csallner-, a Baciu-Matheiu- és a Zikeli-féle nyomda.

A második nagyobb egység hat tanulmánya módszertani szempontból közelíti meg a nemzetközi és a magyar retrospektív bibliográfiai munkálatokat. Nyitásként a VD 16 utolsó, 22. kötetének megjelenése alkalmából készült számvetést olvashatunk. A több mint 98000 tételt felvonultató vállalkozás eredményeként az RMK III kötetei számos új adalékkal gazdagodtak, nem beszélve a tartalmát tekintve magyar vonatkozású nyomtatványok nagy számáról (pl. a tizenöt éves háború haditudósításai).

Ezt követi a retrospektív osztrák nemzeti bibliográfia megindulásáról készült híradás 2001-ből. A mai Ausztria területén megjelent monográfiák, újságok, folyóiratok és speciális bibliográfiák négykötetesre tervezett sorozatából elsőként a Neue Zeitungok első kötete jelent meg. Ebben az 1492-1705 között kiadott újságokról készült leírásokat találjuk, nem kevesebb, mint 18 mutatóval kísérve. A szerző ezúttal is kiemelt figyelmet fordít a magyar vonatkozású kiadványok rendkívüli gazdagságára.

Az osztrák nemzeti bibliográfia után az ÖNB ősnyomtatványkatalógusának indulásáról kapunk hírt ugyanabból az évből. Az első kötet bemutatása kapcsán olyan magyar vonatkozású ritkaságokról szerezhetünk tudomást, mint például Nagylucsei Dóczi Orbán 1480. évi latin Bibliája.

Az osztrák ügyek ismertetése után a magyarországi 1801 előtti retrospektív nemzeti bibliográfia lehetséges irányáról tájékozódhatunk. Az RMNy harmadik kötetének megjelenése kapcsán levont tanulságok, az ott alkalmazott elvek 18. századra vonatkozó tarthatósága vagy tarthatatlansága, az adatgyüjtés és a feltárás sokféle nehézségei (példányszám, kiterjedt szakirodalom, beszükítendő kutatási terület) jól átgondolt rendszerbe foglalva jelennek meg.

A 2000-ben útjára indult Clavis typographorum regionis Carpathicae vállalkozás a huszadik század közepéig a történelmi Magyarország területén müködő 500 nyomdahely és 3400 nyomda részletes adatait tartalmazza (A Clavis typographorum regionis Carpathicae nyitólapján jelenleg elérhető adatok szerint immár 525 nyomdahely, több mint 5500 nyomda és közel 7400 személy vagy testület szerepel az adatbázisban. http://typographia.oszk.hu/html_clavis/hun/nyito.htm [Letöltve: 2019. 07. 15.]). Mindez nem lenne feltárható mindössze a könyvtárakban őrzött kötetek felkutatásával, nemzetközi összefogással végzett aprólékos levéltári forrásfeldolgozással azonban számos új részlettel gazdagítható az adatbázis.

Végül az impresszum nélkül megjelent vagy csonkán fennmaradt kiadványok azonosításához szükséges nyomdahely- és nyomdászmeghatározás módszereivel és határaival ismerkedhetünk meg. A betűtípusok és könyvdíszek kutatásában már jelentős eredményeket mutathat fel a nemzeti könyvtár (lásd például a 2004-ben indult Hungaria typographica sorozat darabjait), s ehhez jön még a nyelvi analízis, amely a régiókra jellemző helyesírási sajátosságokra koncentrál. A szerző megállapítása szerint az ősnyomtatványok azonosítására kidolgozott módszerek a 16. századi hazai nyomtatványok esetében is eredményesek lehetnek.

A kötetet Borsa Gedeon személyi bibliográfiája zárja, amelyben a monográfiáktól és a társszerzőként kiadott munkáktól a kisebb cikkekig és könyvismertetésekig kronológiai rendben tájékozódhatunk. A sorozat többi tagjához hasonlóan a kötet használatát ezúttal is névmutató segíti, a mondandót helyenként régi nyomtatványokból származó illusztrációk támasztják alá.

A retrospektív bibliográfiai-, valamint a könyv- és nyomdászattörténeti kutatásokban gazdag jó hat évtizedes pályafutás méltó köszöntését veheti kézbe az olvasó a „Füzetek” megszokott szolid formájába öltöztetve. A „régikönyves” szakma nevében csatlakozunk a szerkesztőkhöz: Isten éltesse Borsa Gedeont! 